\title{
Karar Ăgacı Algoritmalarıyla Finansal Başarısızlık Tahmini: Dokuma, Giyim Eşyası ve Deri Sektörü Uygulaması
}

\author{
Araştırma Makalesi /Research Article
}

\author{
Duygu ARSLANTÜRK ÇÖLLÜ ${ }^{1}$ \\ Leyla AKGÜN ${ }^{2}$ \\ Ecevit EYDURAN ${ }^{3}$
}

ÖZ: Bu çalıșma, 2016-2018 döneminde Borsa İstanbul (BIST)'da listelenen dokuma, giyim eşyast ve deri sektöründeki şirketlerin finansal başarısızlığının araştırılması, bu durumu etkileyen finansal oranların tespit edilmesi ve veri madenciliği algoritmalarının finansal başarısızlığı tahmin etmedeki güçlerinin test edilmesini sağlamak amacıyla gerçekleştirilmiştir. Bu kapsamda sektörde yer alan 20 şirketin üç yıllık finansal durumu Altman Z skoru yardımıyla değerlendirilmiş ve başarılı ve başarısız şirketler tespit edilmiştir. Ardından çeşitli finansal oranlar kullanılarak, veri madenciliği algoritmalarından CHAID, Exh-CHAID, CART ve QUEST'in şirketleri finansal başarısızlık açısından ne derece doğru sinıflandırdiğl ve finansal başarısızlığl en çok etkileyen faktörlerin neler olduğu tespit edilmeye çalışılmıştır. Yapılan analizler sonucunda kullanıma en uygun tahminleme yönteminin, genel şirket sinıflandırmasını \%95, başarısız şirket sinıfladırmasını ise \%97.6 oranında bir doğruluk payıyla gerçekleştiren CART olduğu belirlenmiştir. Ayrıca başta özsermaye karlılı̆̆ olmak üzere, cari oran, duran varlıkların özsermayeye orani, ticari alacakların aktiflere oranı, stok devir hizı ve faiz karşılama oranının finansal başarıyı etkilediği tespit edilmiştir.

Anahtar Kelimeler: Finansal Performans, Karar A ̆gacı Algoritmaları, Tekstil Sektörü Jel Kodlart: G10, G33, C38, L25

\section{Financial Failure Prediction with Decision Tree Algorithms: Textile, Wearing Apparel and Leather Sector Application}

\begin{abstract}
This study was conducted to investigate financial failures of textile, wearing apparel and leather sector firms listed on the Borsa İstanbul (BIST) during the 2016-2018 period using data mining algorithms i.e. CART, CHAID, Exhaustive CHAID and QUEST. In this context, determining the financial ratios affecting financial failures and comparing the classification performance of the algorithms used is the main purpose of the study. Within this framework, three years' financial performance of 20 firms in the sector were evaluated using Altman-Z score and financially successful and unsuccessful firms were detected. Then classification performances of CART, CHAID, Exhaustive CHAID and QUEST were evaluated based on various financial ratios about correctly classifying firms in the financial failures, and it was tried to ascertain the most influential factors affecting the financial failures. As a result of the statistical evaluations, it was determined that CART was the best algorithm due to general accuracy classification ratio (95\%) and the correct classification of financially unsuccessful firms (97.6\%). It was concluded that financial performance was influenced by return on equity, followed by current ratio, fixed assets/equity ratio, trade receivables/assets ratio, stock turnover and interest coverage ratio.
\end{abstract}

Keywords: Financial Performance, Decision Tree Algorithms, Textile Sector Jel Codes: G10, G33, C38, L25

Geliş Tarihi / Received: 04/03/2020

Kabul Tarihi / Accepted: 14/07/2020

1 Dr. Öğr. Üyesi, Iğdır Üniversitesi, İİBF, İşletme Bölümü, duygu.arslanturk@igdir.edu.tr, orcid.org/0000-0002-8023-3888.

2 Dr. Öğr. Üyesi, Iğdır Üniversitesi, İ̈BF, İşletme Bölümü, leyla.akgun@igdir.edu.tr, orcid.org/0000-0001-5876-0211.

${ }^{3}$ Prof. Dr., Iğdır Üniversitesi, İİBF, İşletme Bölümü, ecevit.eyduran@igdir.edu.tr, orcid.org/00000001-7200-982X. 


\section{Giriş}

Oldukça geniş kapsamlı bir ifade olan "finansal başarısızlık" taşıdığı anlam bakımından belirsizlikler içermektedir. Genel olarak vadesi gelen borcu ödeme zorluğu anlamında kullanılan bu terim, operasyonel tanımı açısından ise bono temerrüdü ve iflas şeklinde iki ana olaya odaklanmaktadır (Beaver, Correia ve McNichols, 2011: 3). Diğer bir ifade ile, bir şirketin adım adım iflasa yaklaşması, tasfiye edilmesi ve başka tür bir yol ile şirkete el koyulması ya da dağıtılması şeklinde cereyan eden bu durumun beraberinde büyük zararlar getireceği açıktır (Ashraf, Felix ve Serrasqueiro, 2019:2). Bu nedenle finansal başarısızlığın öngörülmesi ve önlenmesi yüksek iflas maliyetinin önüne geçilmesini sağlamak üzere analiz edilmesi oldukça önemli bir husustur. Nitekim finansal başarısızlık ve onun getirdiği iflas, hem hissedarlar hem de diğer paydaşlar açısından çeşitli maliyetler doğurmaktadır. Söz konusu maliyetler finansal başarısızlık ihtimalini, herhangi bir şirketin sahipleri, yöneticileri, yatırımcıları, alacaklıları, iş ortakları ve ayrıca finansal piyasaların istikrarını ve genel ekonomik refahı korumaktan sorumlu devlet kurumları için bir önemli bir endişe kaynağı haline getirmektedir (Martin vd., 2011:12).

Bir firmanın başarısı için finansal sıkıntıyı, meydana gelmeden önce tahmin edebilmenin ve bu durumu etkileyen faktörlerin neler olduğunun tespit edilmesinin oldukça önemli olduğu görüşünden hareketle konuya ilişkin bir çok araştırma yapılmıştır. Yapılan araştırmalar kapsamında Beaver (1967) ve Altman (1968) 'in çalışmaları, bazı finansal yapılara sahip firmaların diğer firmalardan daha fazla temerrüt ve nihai iflas olasılığına sahip olduğunu ortaya koymuştur (Martin vd., 2011:12). Bu durum finansal başarısızlığ 1 ve dolayısıyla iflası tahmin etmek üzere çeşitli modellerin geliştirilmesine olanak sağlamıştır. Söz konusu modellerin kullanılmasıyla, birçok firmanın finansal istikrarlarında önemli farkl11ıklar olduğu görülmüş ve hatta iflasa girme olasılıklarının azaltılabildiği tespit edilmiştir. İflasın önlenmesinin ise sadece bir firmanın ekonomik ömrünü uzatmakla kalmadığı, aynı zamanda finansal performansını da $\operatorname{arttırdığı~ve~}$ dolayısıyla bir ülkenin genel ekonomik refahının iyileşmesine hizmet ettiğinin de göz ardı edilmemesi gerekmektedir (Ashraf, Felix ve Serrasqueiro, 2019: 2).

İmalat sanayi altında faaliyet göstererek istihdam, üretim ve ihracatta ilk siralarda yer alan dokuma, giyim eşyası ve deri alt sektörü Türkiye'nin en önde gelen sektörlerinden birisini oluşturmaktadır. 1980'li yıllar itibariyle dişa açık ekonomik büyüme modeli ile uyumlu olarak Türkiye dokuma, giyim eşyası ve deri sektörü, ihracat odaklı bir gelişim göstermiş ve dünya pazarı için önemli bir üretici ve tedarikçi konumuna gelmiştir. Ancak emek yoğun faaliyetlerin gerçekleştirildiği sektör, Uzakdoğu ülkelerinden gelen düşük fiyatlı ürünlerin pazar payını artırmaları nedeniyle rekabet baskısı altındadır (BTSB, 2015:6) Diğer taraftan kullanılan enerji maliyetlerinin yüksek oluşu, hammadde konusunda dişa bağımlılık ve dolayısıyla yüksek girdi maliyetleri, sektörün ihtiyaç duyduğu ileri teknolojili makine üretimi konusundaki yetersizlikler ve özellikle kurlardaki 
yüksek dalgalanmalar sektörün sürdürülebilirliğini tehlikeye düşürmektedir (BTSB, 2015:43). Nitekim 2018 yılında yaşanan kurlardaki ani yükseliş sektörü olumsuz yönde etkilemiş ve yüksek girdi maliyetleri ile sonuçlanan bu durum sektördeki birçok firmanın üretim ve satışlarının oldukça düşük seviyelere inmesine neden olmuştur. Dokuma, giyim eşyası ve deri sektörü firmalarının çeşitli finansal sıkıntılarla karşılaşacağına işaret eden tüm bu olumsuzluklar, söz konusu firmaların finansal sıkıntıya düşme durumlarının önceden tahmin edilmesinin ve bu durumu etkileyen faktörlerin tespit edilmesinin ne denli önemli olduğunu bir kez daha gündeme getirmiştir.

Türkiye'de finansal sıkıntı yaşaması muhtemel dokuma, giyim eşyası ve deri sektörü firmalarını tahmin etmek ve söz konusu finansal sıkıntıyı etkileyen faktörleri tespit etmeye yönelik sınırlı sayıda çalışma bulunmaktadır. Söz konusu çalışmaların sonuçları ise genelleştirilememektedir. $\mathrm{Bu}$ nedenle alternatif tahminleme modelleri kullanılarak Türk dokuma, giyim eşyası ve deri sektörü firmalarının finansal sıkıntılarını değerlendirmek, finansal başarıyı etkileyen faktörleri tespit etmek ve en başarılı sinıflandırma yöntemini belirlemek söz konusu firmaların sürdürülebilirliği açısından oldukça önemlidir. Dolayısıyla bu çalışma, Türkiye'deki dokuma, giyim eşyası ve deri sektörü firmalarının finansal başarısızlıklarını mali oranlar yardımıyla tahmin etmeyi ve en uygun tahminleme yöntemini belirlemeyi amaçlamaktadır. Konuya ilişkin literatürde yer alan çalışmalardan farklı olarak, tahminleme yöntemi olarak veri madenciliği algoritmalarından CHAID, EXHAUSTIVE CHAID (Exh-CHAID), CART ve QUEST'in birlikte ele alındığı çalışmanın, uygun tahminleme yöntemini belirleme, zaman dilimi ve sektör bakımından literatüre katk1 sağlayacağ1 düşünülmektedir. $\mathrm{Bu}$ kapsamda mevcut çalışma beş bölüm şeklinde düzenlenmiştir. Konuya ilişkin genel bilgilerin yer aldığg giriş bölümünü takiben ilgili literatür özetlenmiş, üçüncü bölümde yöntem tanıtılmış, dördüncü bölümde ise bulgulara yer verilmiştir. Son bölümde ise genel bir değerlendirme yapılmış ve çalışma tamamlanmıştır.

\section{Literatür Araştırması}

Başta ABD'de olmak üzere 1930'lu yıllardan itibaren finansal başarısızlığın öngörülmesine yönelik çok sayıda çalışma yapılmıştır. Bellovary, Giacomino ve Akers (2007)'e göre, konuya ilişkin ilk çalışma 1930'da 'Bureau of Business Research" tarafindan yayınlanan başarısız olan endüstriyel firmaların finansal oranlarının incelenmesiyle ortaya çıkmıştır. Çalışmada, başarısız firmaların ortak özelliklerini belirlemek üzere 29 firma, 24 oran yardımıyla analiz edilmiştir. Sonuçlar başarısız olan firmaların bazı benzer özellikler veya eğilimler gösterdiğini ortaya koyan bazı oranların mevcut olduğunu göstermiştir. Nihayetinde bir firmanın zayıflığının arttığının göstergesi olarak kabul edilen sekiz oran tespit edilmiştir (Bellovary, Giacomino ve Akers, 2007: 2). Söz konusu çalışmayı takiben benzer birkaç çalışma (Fitzpatrick (1932), Smith ve Winakor (1935), Chidson (1945) gibi) daha yapılmış ancak Beaver (1966) başarılı ve 
başarısız firmaları sınıflandırmada bireysel finansal oranların tahmin edici yeteneklerini test ederek çalışmasını bir adım daha ileri taşımıştır (Bellovary, Giacomino ve Akers, 2007: 4). Böylece Beaver (1966) finansal başarısızlığ tahmin etmek üzere başarılı ve başarısız firmaların bir dizi finansal oranına tek değişkenli bir model olan "tek değişkenli diskriminant analizi" uygulayan ilk araştırmacı olmuştur (Balcaen ve Ooghe, 2004: 6).

Beaver (1966), 38 sektördeki başarısız kabul edilemeyecek 79 firma ile başarısız 79 firmanın durumunu 30 finansal oran yardımıyla değerlendirmiştir. Oranların ayrı ayrı ele alındığı çalışmada, başarılı ve başarısız firmaların sınıflandırmalarında yanlışs sınıflandırma yüzdesinin en aza indirildiği optimum bir kesme noktası tespit edilmeye çalışılmışıtır. Beş yıl önceki veriler kullanılarak çalışmada yer alan finansal oranların öngörücü yetenekleri test edilmiştir. Sonuçlar nakit akışının toplam borçlara oranının \%78'lik başarı ile beş yıl önceden başarısızlığı tahmin etmede en önemli faktör olduğunu ortaya koymuştur. Ancak Pogue (2008)'e göre, Beaver (1966)'ın finansal başarısızlığın öngörülmesinde tek değişkenli analizleri kullanması, aynı şirkette ilişkin farklı oranlarla yapılan sınıflandırma sonuçlarını kafa karıştıııcı ve yanıltııı bir hale getirebilmektedir. Bu konudaki eksikliği dikkate alan Altman (1968), başarısızlık öngörüsü için bir çok değişkeni birlikte analiz edebilen bir modeli kullanan ilk araştırmaci olmuştur.

Altman (1968), 1946-1965 döneminde çoklu diskriminant analizini kullanarak finansal başarısızlığ 1 tahmin etmek üzere bir model geliştirmiştir. İmalat sektöründeki firmaların değerlendirildiği çalışmada 33 iflas etmiş ve 33 iflas etmemiş firmaya ilişkin 22 finansal oran kullanılmıştır. Oranlar, karlılık; likidite; kaldıraç; ödeme gücü ve aktivite olmak üzere beş farklı kategoride toplanmıştır. Çalışma sonucunda Altman (1968), net çalışma sermayesinin toplam aktiflere oranı; dağıtılmamış karın toplam aktiflere oranı; faiz ve vergi öncesi karın toplam aktiflere oranı; hisselerin piyasa değerinin borçların defter değerine oranı; net satı̧̧ların toplam aktiflere oranı şeklindeki beş finansal oran yardımıyla $Z$ skor modelini ${ }^{4}$ oluş̧urmuş ve hesaplanan $\mathrm{Z}$ puanları ile sağlıklı bir şirketin sağlıksız bir şirketten ayrıştırılmasını sağlamıştır. Modele göre bir şirketin $Z$ puanı 2, 99'u aştığında güvenli; $\mathrm{Z}$ puanı 1.81 'den düşük olduğunda ise potansiyel olarak başarısız olduğu kabul edilmektedir. 1.81 ile 2.99 arasındaki $\mathrm{Z}$ puanları ise gri alan olarak değerlendirilmektedir. Sonuçta Altman (1968)'ın modelinin bir şirketin başarısızlığını önceki bir yıl içinde \%95, önceki iki yıl içinde ise \% 83'lük yüksek bir oranla doğru tahmin ettiği belirlenmiştir.

1968'den bu yana, Altman modeli finansal başarısızlık tahmini literatüründe yaygın olarak kullanılmıştır, ancak çoklu diskriminant analizi tekniği çok değişkenli normallik ve açıklayıcı değişkenlerin bağımsızlığı şeklindeki kısıtlayıcı varsayımları nedeniyle net bir şekilde eleştirilmiştir (Ohlson, 1980:112). Bu

${ }^{4}$ Modele ilişkin detaylı bilgiler bağımlı değişken açıklanırken metodoloji kısmında sunulmuştur. 
sınırlamaların üstesinden gelmek için Ohlson (1980), dokuz finansal oranlı bir dizi logit analizine dayanan yeni bir model önermiştir. Log (reel aktifler), toplam borçlar/toplam varlıklar, net işletme sermayesi/toplam varlıklar, kısa vadeli yükümlülükler/dönen varlıklar, toplam yükümlülükler ile toplam varlıkları kıyaslayan gösterge değişken, net kâr/toplam varlıklar, faaliyetlerden sağlanan nakit/toplam yükümlülükler, son iki yılın net gelirin negatif olmasına bağlı kukla değişken, net kâr değişimi şeklindeki oranlar kullanılarak 1970-1976 yılları arasında 105 iflas etmiş ve 2058 iflas etmemiş firma analiz edilmiştir. İflastan bir yıl öncesi, iki y1l öncesi ve birlikte değerlendirilen bir-iki yıl öncesi için üç farklı logit model geliştirmiştir. Sonuçlar modelin iflastan bir yıl öncesi için \%96; iki yıl öncesi için \% 95.55; bir-iki yıl öncesi için ise \%92,84 oranında başarıyla tahminde bulunduğunu ortaya koymuştur.

Zmijewski (1984), 1972-1978 yılları arasında Amerikan ve NewYork borsasına kayıtlı (finans, hizmet ve kamuya ait firmalar hariç) iflas ilan etmiş 40 firma ile iflas etmememiş 800 firmayı değerlendirmiştir. İflas tahmin modelini oluşturmak üzere probit tekniğini kullanan Zmijewski (1984), açıklayıcı değişkenler olarak net kar/toplam aktifler, toplam borçlar/toplam aktifler ve dönen varlıklar/kısa vadeli borçları kullanmıştır. Söz konusu model ile firmaların performans, kaldıraç ve likidite durumlarının analiz edilebildiği kabul edilmektedir. Çalışma sonucunda Zmijewski (1984) modelin, iflası gerçekleşmeden iki yıl önce tahmin etmede $\% 99$ doğruluk oranına ulaştığını iddia etmiştir.

Yukarıda konuya ilişkin öncü çalışmalar dikkate alındığında finansal başarısızlığı tahmin etmek üzere farklı modellerin kullanıldığı ve bu kapsamda Beaver (1966) ve Altman (1968)'ın çalışmalarında sırasıyla, tek değişkenli ve çok değişkenli diskriminant analizleri yaptıkları, Ohlson (1980)'un ise ABD'deki firmalarda başarısızlığın öngörülmesini sağlamak üzere parametrik bir yaklaşım olan koşullu logit modelini uygularken, Zmijewski (1984)'nin probit modelinden faydalandığ görülmektedir. Ancak söz konusu çalışmalarda yer alan modellerin tamamının statik bir başarısızlık durumunu varsayan kesitsel modeller olmaları yeni model arayışlarının sürmesine neden olmuştur (Gupta, 2017:99).

2000'li y1llara kadar geliştirilen diğer modeller olarak; Messier ve Hansen (1988)'in uzman sistemler modeli, Guan (1993), Tsukuda ve Baba (1994), Altman, Marco ve Varetto (1994), Boritz ve Kennedy (1995), Lee, Han ve Kwon. (1996)'nın sinir ağları modeli, Vermeulen, Spronk ve Wijst (1998)'nin çok faktörlü modelleri dikkate alınabilir. Sonrasındaki yıllarda ise yapılan çalışmaların genellikle karar ağacı modelleri etrafında toplandığı görülmektedir. Nitekim, Zheng ve Yanhui (2007) ve Andreica (2012) kurumsal finansal sikıntı tahmini için karar ağacı modellerini kullanmış ve CHAID karar ağaçlarını kullanmanın bir sinir ağı modeline kıyasla avantajlarını sunmuşlardır. Diğer taraftan finansal başarısızlığı tahmin etmede Chen vd.(2006), Sun ve Li (2008), Nie vd. (2011) karar ağacı modellerini, Martin vd. (2011) genetik algoritmalar ve MARS'1, Bruwer ve Hamman (2006), Lee vd. (2006) CART'yi kullanmanın tahmin gücünü 
artıracağını ifade etmişlerdir. Ayrıca adı geçen karar ağacı ve MARS modellerinin gerçekçi olmayan varsayımlarda bulunmadan açıklayıcı özellikler arasındaki karmaşık ilişkiyi dikkate alması ve ayrıca, CART ve MARS modellerinin, büyük eğitim veri setleri gerektirmemesi avantajlı modeller olarak görülmelerine neden olmuştur (Mabe ve Lin, 2018:4).

Türkiye'de de konuya ilişkin birçok çalışma yapılmıştır. Yapılan çalışmaların bir kısmı Altman Z skorunun geçerliliğini test ederken diğer bir kısmı ise farklı modeller kullanmayı tercih etmiştir. Altman Z skoru modelinin geçerliliğini test etmek üzere yapılan çalışmalardan biri İçerli ve Akkaya (2006) tarafından gerçekleştirmiştir. Z skor modeli ile finansal başarısızlığın en büyük nedeninin yönetim hataları olduğunu ve daha etkin bir yönetimle finansal başarıya ulaşabilecekleri ifade edilmiştir. Aynı yöntemi kullanan Kulalı (2016), 2000-2013 yıllarında Borsa İstanbul'a kote olan iflas etmiş şirketlerin verileri yardımıyla Altman Z skor modelinin tahmin gücünün oldukça yüksek olduğu sonucuna ulaşmıştır. Yılmaz ve Yıldıran (2015) da, modelin tahmin kapasitesini, BIST'de faaliyet gösteren 18'i iflas etmiş firma ile 18 başarılı firmanın verilerini kullanarak analiz etmiştir. Bulgular Altman'ın Z skorunun başarılı firmaları tahmin etmede $\% 89$, başarısı firmaları tahmin etmede ise $\% 71$ başarı gösterdiğini ortaya koymuştur.

Ülkemizde yapılan çalışmalar kapsamında, Altman'ın Z skoru yerine finansal başarısızlık tahmini için farklı modeller kullanan araştırmaların da yapıldığı görülmektedir. Nitekim Akkaya, Demireli ve Yakut (2009), tekstil ve kimya, petrol ve plastik sektörlerinde faaliye gösteren 21 firmanın finansal başarısızlığını yapay sinir ağlarını kullanarak bir yıl önceden tahmin etmeyi hedeflemiştir. Sonuçlar yapay sinir ağları ile yapılan tahminin başarılı firmalar için \%82, başarısız firmalar için ise \%80 oranında doğru olduğunu ortaya koymuştur. Yapay sinir ağlanırının kullanıldığı bir diğer çalışma Kurtaran Çelik (2010) tarafından gerçekleştirilmiştir. Kurtaran Çelik (2010) bankaların finansal başarısızlıklarını tahmin etmek üzere yapay sinir ağları ve diskriminant analizini kullanarak bir erken uyarı modeli geliştirmeyi amaçlamıştır. 36 adet özel sermayeli ticaret bankasının çeşitli mali oranları kullanılarak bir ve iki yıl önceden finansal başarısızlık tahmin edilmeye çalışılmıştır. Yapay sinir ağları başarısızlık tahmininin bir yıl önceden \%100, iki yıl önceden ise \%88 başarıyla tahmin ederken diskriminant analizi bir ve iki yıl önceden \%91 başarı ile tahmin etmiştir. Yapay sinir ağlanırının tahmin güçlerinin oldukça yüksek olduğunu gösteren çalışmaları takiben farklı bir yöntem olarak finansal başarısızlık öngörüsü için Y1lgör, Doğrul ve Temel (2011) sinıflandırma ve regresyon ağacı (CART)'nı kullanmıştır. Bulgular CART'nin başarısızlıktan bir, iki ve üç y1l önce finansal başarısızlığı tahmin etme gücünün yüksek olduğunu ve karlılık oranlarının başarısızlık tahmininde en önemli oranlar olduğunu ortaya koymuştur. Ural, Gürarda ve Önemli (2015) ise, finansal başarısızlığı tahmin etmek üzere lojistik regresyon modelini kullanmışlardır. Borsa İstanbul'da faaliyet gösteren gıda, içki ve tütün şirketlerinin finansal olarak başarısızlık ihtimalini lojistik modeli 
kullanarak üç y1l öncesinden tahmin etmeyi hedeflediği çalışmada modelin tahmin gücünün bir ve iki yıl için \%91, üç yıl için ise \%74,5 olduğu tespit edilmiştir.

Konuya ilişkin yerli literatürde mevcut çalışmanın ele aldığı dokuma, giyim eşyası ve deri alt sektörüne ilişkin olarak yapılan çalışmalara da rastlanmıştır. Bu kapsamda Altaş ve Giray (2005), çalışmalarında 2001 yılı tekstil sektöründe faaliyet gösteren İMKB'ye kayıtlı işletmelerin finansal başarısızlıklarını tahmin etmek üzere lojistik regresyon analizini kullanmışlardır. Sonuçlar İMKB'ye kayıtlı tekstil firmalarının mali başarısızlığını belirleyen en önemli faktörün likidite faktörü olduğu ortaya koymuştur. Selimoğlu ve Orhan (2015), Borsa İstanbul'da 2013 yılında faaliyet gösteren 25 dokuma, giyim eşyası ve deri işletmelerinin finansal başarısızlıklarının ölçümlenmesinde yararlanılabilecek finansal oranları belirlemek üzere bir araştırma yapmışlardır. 23 adet finansal oran kullanılarak yapılan çok değişkenli analiz sonucunda "duran varlıklar/özkaynaklar, faiz karşılama, faaliyet kör marjı, net kâr marjı, özkaynak kârlılığı, aktif kârlılığı ve faiz ve vergi öncesi kar (FVÖK)/aktif toplamı" oranlarının başarılı ve başarısız gruplar arasında anlamlı bir farklılık gösterdiği tespit edilmiştir. Bu yedi oran kullanılarak gerçekleştirilen diskriminant analizi sonucunda, modelin \%92 oranında doğru sınıflandırma yaptığı belirlenmiştir.

\section{Araştırma Metodolojisi}

BIST'de imalat sektörü altında faaliyet gösteren 23 adet "Dokuma, Giyim Eşyası ve Deri" firmasının finansal başarısızlıklarını tahmin etmede kullanılabilecek bir model önermek üzere hazırlanan bu çalışmada 2016, 2017, 2018 yılllarına ilişkin olarak tüm verilerine ulaşılabilen 20 şirket üzerinden analizler gerçekleştirilmiştir. $\mathrm{Bu}$ kapsamda çalışmanın bu bölümünde, ilk olarak araştırmanın bağımlı ve bağımsız değişkenlerine yer verilmekte; sonrasında ise araştırmada kullanılan yöntemler açıklanmaktadır.

\subsection{Araştırmanın Değişkenleri}

Bağımlı Değişkenler: Mevcut çalışmada bağımlı değişken olarak finansal başarı durumu dikkate alınmıştır. Başarılı veya başarısız olmak üzere iki seviyesi olan söz konusu kategorik değişkene ulaşmak üzere Altman $Z$ skorundan yararlanılmıştır.

Altman Z skoru: Altman'in, çeşitli katsayılarla oranların çarpılması sonucu oluşturulan Z Skor formülü eşitlik (1)'de sunulmuştur (Altman, 2000: 9):

$$
\text { Z Skor }=1,2 X_{1}+1,4 X_{2}+3,3 X_{3}+0,6 X_{4}+1,0 X_{5}
$$

Burada;

$\mathrm{X}_{1}$ : Net çalışma sermayesi/ Toplam aktifler

$\mathrm{X}_{2}$ : Dağıtılmamış karlar/ Toplam aktifler

$\mathrm{X}_{3}$ : Faiz ve vergi öncesi kar/ Toplam aktifler 
$\mathrm{X}_{4}$ : Hisselerin piyasa değeri/ Borçların defter değeri

$\mathrm{X}_{5}$ : Net satışlar/ Toplam aktifler oranını temsil etmektedir.

Yukarıda gösterilen eşitlik yardımıyla elde edilen değerler Altman'ın belirlediği referans değerler ile karşılaştırılarak, söz konusu firmanın finansal olarak başarılı mı yoksa başarısız mı olduğuna karar verilmektedir. Bu kapsamda Altman (1968) tarafından belirlenen referans değerler aşağıda yer almaktadır.

- Z skoru > 2.99 ise, finansal olarak güvenli bölge

- $1.81<Z$ skoru $<2.99$ ise, gri bölge

- Z skoru < 1.81 ise, finansal olarak tehlikeli bölge olarak adlandırılmıştır.

Buna göre, güvenli bölgedeki şirketlerin finansal olarak sağlıklı ve başarılı oldukları, gri bölgedekilerin herhangi bir yöne gidebilecekleri ve tehlikeli bölgedeki şirketlerin ise, başarısız ve iki yıl içinde iflas etme risklerinin yüksek olduğu kabul edilebilmektedir (Kumar ve Rao, 2014:86).

Altman, ilk geliştirdiği Z skor modelini takiben modelde değişiklikler yaparak halka açı olmayan şirketlerin de finansal başarı durumlarının değerlendirilebilmesini sağlamak üzere ZETA modelini oluşturmuştur. Sadece imalat sektörünü kapsaması bakımından eleştirilen bu iki modelin sonrasında ise hizmet sektöründe kullanılmak üzere $\mathrm{Z}$ skor modelinde değişiklikler yapılarak üçüncü bir model geliştirmiştir. Ancak mevcut çalışmada hem borsaya kote halka açık firmalar hem de imalat sektörü firmaları dikkate alındığından eşitlik (1)'de yer alan ilk model kullanılmıştır.

Çalışmada eşitlik (1) yardımıyla üç yıla ilişkin $Z$ skorları hesaplanmış ve ortalaması alınmıştır. Z skorları 1.81'in altında kalan firmalar başarısız kabul edilirken, diğer firmaların ise Terzi (2011), Selimoğlu ve Orhan (2015) ve Gör (2019) ile uyumlu olarak başarısız olmadıkları kabul edilmiştir.

\section{Bă̆ımsız Değişkenler:}

Bir firmanın faaliyet durumunun ve finansal zorluklarının tespit edilmesi finansal oranlar yardımıyla analiz edilmeye elverişli bir durumdur (Altman, 2000:8). Bu kapsamda genellikle konuya ilişkin yapılan çalışmalarda finansal oranlar popülerlikleri ve öngörü kabiliyetleri nedeniyle bağımsız değişkenler olarak seçilmiştir (Altman, 1968; Beaver, 1966; Ohlson, 1980). Ayrıca finansal oranların basitliği ve firmanın yerel çevresi ile olan ilgileri de bağımsız değişken olarak kabul edilmelerinde etkili olan faktörler olarak gösterilmiştir (Alifiah ve Tahir, 2018:595). Bu çalışmada da literatürdeki çalışmalara benzer şekilde bağımsız değişkenler olarak likidite, aktivite, sermaye yapısı ve karlılık oranlarından oluşan 23 oran kullanılmış ve Tablo 1'de gösterilmiştir. 
Tablo 1: Bağımsız Değişkenler

\begin{tabular}{|c|c|c|}
\hline Değişkenler & Hesaplanış Şekli & Kaynak \\
\hline Cari Oran (CO) & Dönen Varlıklar/Kısa Vadeli Borçlar & Ohlson (1980), Zmijewski (1984) \\
\hline Asit Test oranı (ATO) & $\begin{array}{l}\text { Dönen Varlıklar-Stoklar/Kısa Vadeli } \\
\text { Borçlar }\end{array}$ & Delen, Kuzey ve Uyar (2013) \\
\hline Nakit Oranı (NO) & Hazır Değerler/Kısa Vadeli Borçlar & Delen, Kuzey ve Uyar (2013) \\
\hline Stokların Aktiflere Oranı (SAO) & Stoklar/Toplam Aktifler & Yerdelen, Tazegül ve Yazarkan (2016) \\
\hline $\begin{array}{l}\text { Ticari Alacakların Aktiflere } \\
\text { Oranı (TAAO) }\end{array}$ & Ticari Alacaklar/Toplam Aktifler & Ertan ve Ersan (2018) \\
\hline Alacak Devir Hızı (ADH) & Net Satışlar/Ticari Alacaklar & Delen, Kuzey ve Uyar (2013) \\
\hline Stok Devir Hızı (SDH) & $\begin{array}{l}\text { Satışların Maliyeti/Stoklar (NET } \\
\text { SATIS SMM) }\end{array}$ & Selimoğlu ve Orhan (2015) \\
\hline Dönen Varlık Devir hızı (DöDH) & Net Satışlar/Dönen Varlıklar & Delen, Kuzey ve Uyar (2013) \\
\hline Özsermaye Devir Hızı (ÖDH) & Net Satışlar/Özsermaye & Delen, Kuzey ve Uyar (2013) \\
\hline Aktif Devir Hızı (AkDH) & Net Satışlar/Toplam Aktifler & Altman (1968) \\
\hline $\begin{array}{l}\text { KVB'un Özsermayeye Oranı } \\
\text { (KÖO) }\end{array}$ & Kısa Vadeli Borç/Özsermaye & Yerdelen, Tazegül ve Yazarkan (2016) \\
\hline Özsermaye Oranı (ÖO) & Toplam Borç/Özsermaye & Altman vd. (2014) \\
\hline $\begin{array}{l}\text { Duran Varlıklar/ Özsermaye } \\
\text { Oranı (DVÖO) }\end{array}$ & Duran varlık/Özsermaye & Selimoğlu ve Orhan (2015) \\
\hline KVB'un Aktiflere Oranı (KAO) & Kısa Vadeli Borç/Toplam Aktifler & Blums (2003) \\
\hline UVB’un Aktiflere Oranı (UAO) & Uzun Vadeli Borç/Toplam Aktifler & Ertan ve Ersan (2018) \\
\hline Toplam Borç Oranı (TBO) & Toplam Borç/Toplam Aktifler & $\begin{array}{l}\text { Ohlson (1980), Zmijewski (1984), } \\
\text { Shumway (2001) }\end{array}$ \\
\hline Faiz Karşılama Oranı (FKO) & Faiz ve Vergi Öncesi Kar/Faiz & Selimoğlu ve Orhan (2015) \\
\hline Brüt Kar Marjı (BKM) & Brüt Kar/Net Satışlar & Selimoğlu ve Orhan (2015) \\
\hline Faaliyet Kar Marjı (FKM) & Faaliyet Karı/Net Satışlar & Selimoğlu ve Orhan (2015) \\
\hline Net Kar Marj1 (NKM) & Net Kar/Net Satışlar & Delen, Kuzey ve Uyar (2013) \\
\hline Özsermaye Karlılı̆̆ı (ÖK) & Net Kar/Özsermaye & Delen, Kuzey ve Uyar (2013) \\
\hline Aktif Karlılığg (AK) & Net Kar/Toplam Aktifler & Ohlson (1980), Zmijewski (1984) \\
\hline
\end{tabular}




\subsection{Araștırmada Kullanılan Yöntemler}

Firmaların finansal başarısızlıklarını doğru şekilde tahmin etmek piyasa katılımcıları olan hissedarlar, potansiyel yatırımcılar, kreditörler ve yasal düzenlemeler için devlet açısından oldukça önemlidir. $\mathrm{Bu}$ nedenle finansal başarısızlığı tahmin etmek üzere literatürde çok sayıda çalışma yapılmış ve tahminleme işlemi için bir çok model geliştirilmiştir. Nitekim konuya ilişkin literatürün yer aldığı ikinci bölümde de bu yöntemlere ilgili örnekler sunulmuştur. Bu kapsamda finansal başarısızlığı tahminleme yöntemi olarak daha çok doğrusal modellerin kullanıldığ 1 bilinmektedir. Ancak doğrusal modeller, basit ve yorumlanması kolay olmasına rağmen, gerçekçi olamayacak istatistiksel varsayımlar gerektirirken, alternatif bir yöntem olarak geliştirilen sinir ağlarının da kavramayı zorlaştıracak bir karmaşıklığa sahip olduğu bilinmektedir. Veri madenciliği algoritmalarının en etkin yaklaşımlarından biri olan karar ağaçları, tahminleme için kullanılabilecek güncel yöntemlerden birisidir. Ağaç şeklinde bir görünüme sahip olan model kolayca anlaşılabilir bir yapıya sahip olmasının yanısıra, doğrusal olarak ayrılmayan kalıpları ayırt etmede kullanılmak üzere oldukça faydalıdır (Zheng ve Yanhui, 2007:1-2). Tüm bu avantajları dikkate alındığında mevcut çalışmada CHAID, Exh-CHAID, CART ve QUEST karar ağaçlarından yararlanılmıştır.

Ele alınan karar ağacı algoritmalarının sınıflama performanslarının ölçülmesinde, genel doğru sinıflama oranı (general classification accuracy ratio), başarısız olan firmaların doğru sınıflama oranı (sensitivity) ve başarılı olan firmaların doğru sınıflama oranı (specificity) ölçütleri kullanılmıştır (Grzesiak and Zaborski, 2012). Tüm istatistiksel değerlendirmeler IBM SPSS 23 programı kullanılarak yapılmıştır.

\section{Bulgular}

BIST'te faaliyet gösteren dokuma, giyim eşyası ve deri firmalarının finansal başarısızlıklarını finansal oranlar yardımıyla tahmin etmek ve en uygun sınıflandırma yöntemini belirlemek amacıyla veri madenciliği algoritmalarından CHAID, Exh-CHAID, CART ve QUEST metodlarının kullanıldığı çalışmaya ilişkin elde edilen bulgular aşağıda sunulmuştur.

\subsection{CHAID Algoritmasına İlişkin Sonuçlar}

Dokuma, giyim eşyası ve deri alt sektöründe faaliyet gösteren firmaların finansal başarısızlık durumlarını ortaya koymak amacıyla CHAID algoritması kullanılarak sınıflandırma ağacı diyagramı oluşturulmuştur. CHAID algoritması finansal başarısızlığı \%95.1 oranında doğru sınıflandırırken, genel olarak başarıbaşarısızlık durumunu ise \%93.3 oranında doğru sınıflandırmıştır. 


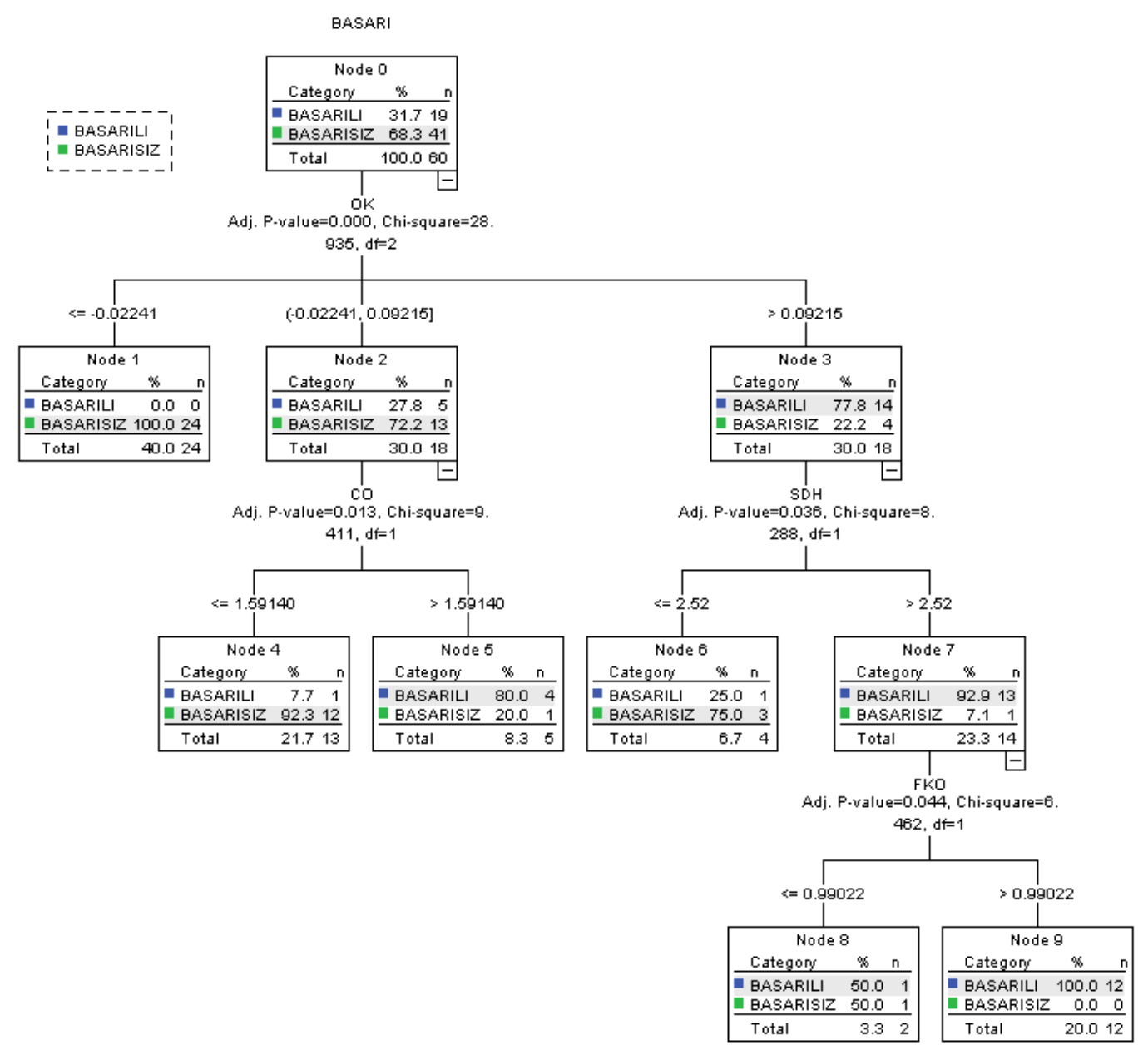

CHAID sınıflandırma ağacinın en tepesinde bulunan kök düğüm (Düğüm 0) incelendiğinde araştırmaya konu olan firmaların \%68.3'ünün başarısız olduğu belirlenmiştir. Birinci ağaç derinliğinde, Düğüm 0 'da bulunan tüm firmalar özsermaye karlılığı (OK) bakımından Düğüm 1 (OK değeri $\mathrm{OK} \leq-0.02241$ olan firmalardan oluşan alt grup), Düğüm 2 (OK değeri $-0.02241<\mathrm{OK} \leq 0.09215$ olan firmalardan oluşan alt grup) ve Düğüm 3 (OK değeri OK > 0.09215 olan firmalardan oluşan alt grup) olmak üzere üzere üç alt gruba ayrılmıştır.

Düğüm 1 incelendiğinde, OK değeri $\leq-0.02241$ olan firmaların finansal olarak tamamının başarısız olduğu tespit edilmiştir. Başarısızlık oranı, özsermaye karlılığı oranının artışına paralel olarak Dügüum 2'de \%72.2'ye düşerken, Dügüü 3'de \%22.2'ye kadar gerilemiştir. Özsermaye karlılı̆̆ değeri, $-0.02241<\mathrm{OK} \leq$ 0.09215 olan firmalar (Düğüm 2), cari oran (CO) bakımından Düğüm 4 ve Düğüm 5 olmak üzere iki alt gruba ayrılmıştır. Özsermaye karlılığı değeri, - 
$0.02241<\mathrm{OK} \leq 0.09215$ ve cari oran $1 \leq 1.59140$ olan firmaların oluşturduğu alt grup olan Düğüm 4'de finansal başarısızlık oranının \%92.3 olduğu saptanmıştır. Ancak bu oranın Dügüm 5 (OK değeri $-0.02241<\mathrm{OK} \leq 0.09215$ ve CO değeri CO > 1.59140 olan firmalar) için \%20’ye kadar düştüğü görülmektedir.

Özsermaye karlılığ değeri 0.09215 'ten büyük olan firmalardan oluşan alt grup (Dügüm 3), stok devir hızı (SDH) bakımından Düğüm 6 ve Düğüm 7 olmak üzere iki alt gruba ayrılmıştır. OK $>0.09215$ ve SDH değeri $\leq \% 2.52$ olan firmaların oluşturduğu Düğüm 6'da finansal başarısızlık oranının $\% 75$ olduğu görülmektedir. Stok devir hızının > 2.52 olması durumu (Düğüm 7)'nda ise başarısızlığın \%7.1'e kadar düştüğü belirlenmiştir.

Düğüm 7, faiz karşılama oranı (FKO) bakımından Düğüm 8 (OK > 0.09215, SDH $>2.52$ ve $\mathrm{FKO} \leq 0.99022$ olan firmaların yer aldığı alt grup) ve Düğüm 9 (OK > $0.09215, \mathrm{SDH}>2.52$ ve FKO > 0.99022 olan firmaların yer aldığ 1 alt grup) olmak üzere iki alt gruba ayrılmıştır. Düğüm 8 'de yer alan firmaların finansal başarısızlık oranı \%50 olarak hesaplanırken, önemli bir bulgu olarak Düğüm 9'da yer alan firmaların tamamının finansal olarak başarılı olduğu tespit edilmiştir.

\subsection{Exh-CHAID Algoritmasına İlişkin Sonuçlar}

Exh-CHAID algoritması firmaları sınıflandırmada, CHAID sonuçlarına kıyasla daha düşük bir performans göstermiş ve başarısız firmaları \%78 oranında doğru sınıflandırırken, genel sınıflandırmayı \%85 oranında doğru sınıflandırmıştır.

Exh-CHAID sınıflandırma ağacının en üst noktasında yer alan Düğüm 0’a göre araştırılan firmaların \%68,3' ünü başarısız firmalar oluşturmaktadır. Ayrıca Düğüm 0, özsermaye karlılığı bakımından Düğüm $1(\mathrm{OK} \leq 0,09215)$ ve Düğüm 2 $(\mathrm{OK}>0.09215)$ şeklinde iki alt gruba ayrılmıştır. Dügüum 1'de yer alan firmaların finansal başarısızlık oranı \%88,1 iken, özsermaye karlılığının 0.09215 değerinden büyük olduğu Düğüm 2'de başarısızlık oran1 \%22.2'ye düşmüştür.

Düğüm $1(\mathrm{OK} \leq 0,09215)$ cari oran değeri bakımından Dügüm 3 (OK $\leq 0,09215$ ve $\mathrm{CO} \leq 1.59140$ olan firmaların oluşturduğu alt grup) ve Dügüm 4 (OK $\leq$ 0,09215 ve $\mathrm{CO}>1.59140$ olan firmaların oluşturduğu alt grup) olmak üzere ilk alt gruba ayrılmıştır. $\mathrm{OK} \leq 0,09215$ ve $\mathrm{CO} \leq 1.59140$ olan firmaların oluşturduğu Düğüm 3'ün finansal başarısızlık oranının \%97.1 olduğu görülmektedir. Cari oran'ın 1.59140 değerinin üzerinde olması durumunda ise başarısızlık oranının $\% 50$ 'ye indiği tespit edilmiştir.

Exh-CHAID algoritmasının önemli bulduğu bir diğer faktör olan nakit oranı (NO) Düğüm 3 'ün alt gruplara ayrılmasında etkili olmuştur. Nitekim Dügüum 3; Düğüm $5(\mathrm{OK} \leq 0,09215, \mathrm{CO} \leq 1.59140$ ve $\mathrm{NO} \leq 0.08778$ olan firmaların oluşturduğu alt grup), Dügüum $6(\mathrm{OK} \leq 0,09215, \mathrm{CO} \leq 1.59140$ and $0.08778<\mathrm{NO} \leq 0.20035$ olan firmaların oluşturduğu alt grup) ve Düğüm 7 (OK $\leq 0,09215, \mathrm{CO} \leq 1.59140$ ve NO > 0.20035 olan firmaların oluşturduğu alt grup) olmak üzere üç alt gruba ayrılmıştır. Buna göre Düğüm 5 ve Düğüm 7 alt grubunda yer alan tüm firmalar 
tamamıyla başarısız olarak sınıflandırılmıştır. Düğüm 6' da yer alan firmaların ise başarısızlık oranı $\% 50$ olarak belirlenmiştir.

Şekil 2: Exh-CHAID Sınıflandırma Ağacı

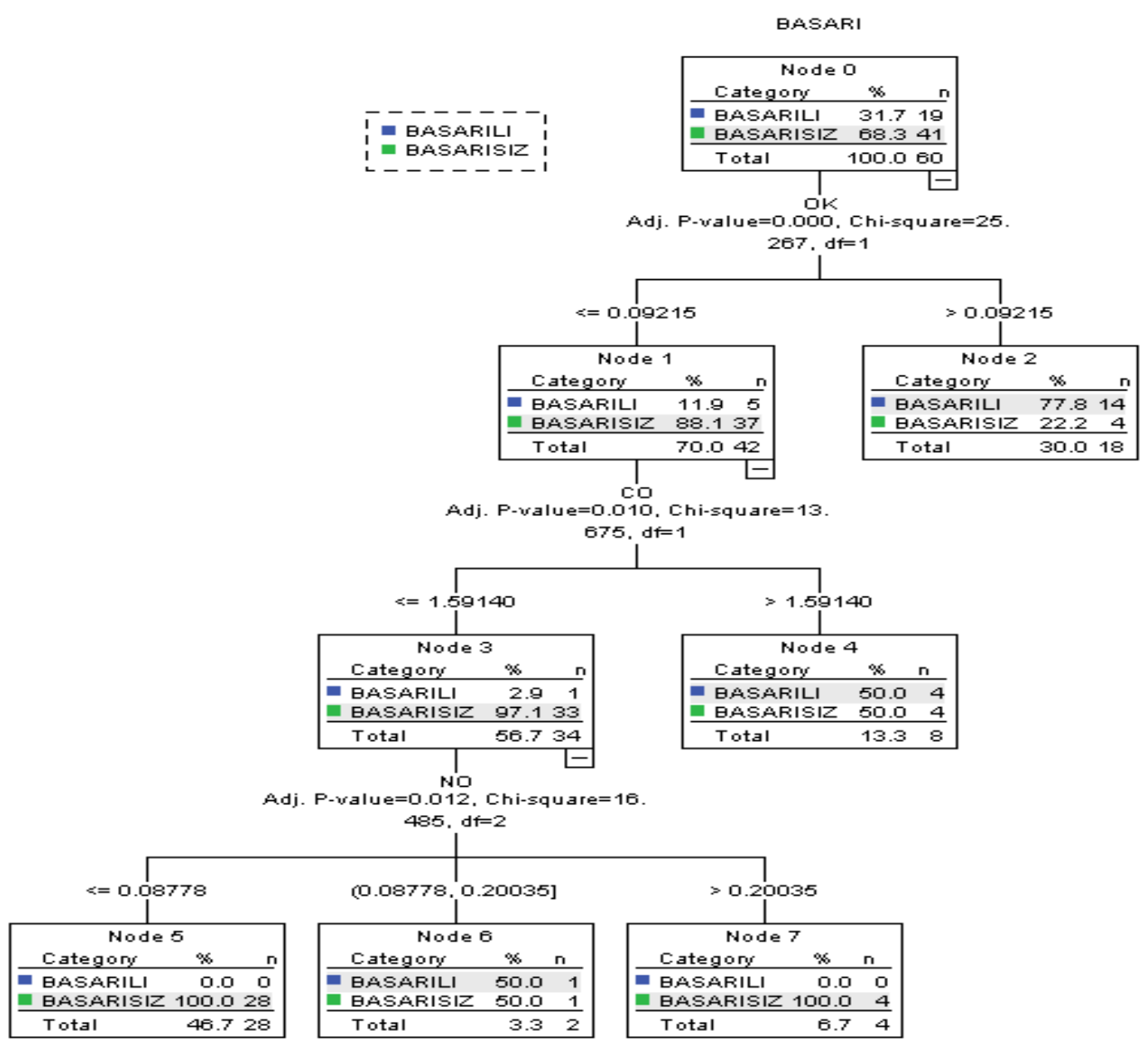

\subsection{CART Algoritmasına İlişkin Sonuçlar}

Çalışmada kullanılan karar ağacı algoritmaları arasında en doğru sınıflandırmayı yapan algoritmanın CART olduğu tespit edilmiştir. CART başarısız firmaları \%97.6 oranında doğru sınıflandırırken, genel sınıflandırmayı ise \%95 oranında bir doğruluk payı ile gerçekleştirmiştir. Söz konusu algoritma sınıflandırma işlemi yaparken OK, CO, duran varlıkların özsermayeye oranı (DVOO) ve ticari alacakların aktiflere oranı (TAAO) bağımsız değişkenlerini dikkate almıştır.

Karar ağacının en başında yer alan Düğüm 0, diğer algoritmalarla uyumlu olarak öncelikle özsermaye karlılığı oranı bakımından Dügüm 1 (öz sermaye karlılığı OK $\leq 0.11011$ olan firmaalrın oluşturduğu alt grup) ve Düğüm 2 (öz sermaye 
karlılı̆̆ $\mathrm{OK}>0.11011$ olan firmaların oluşturduğu alt grup) şeklinde iki alt gruba ayrılmıştır. Düğüm 1'de finansal başarısızlık oranının \%88.4 olduğu görülürken, özsermaye karlılık Oranının 0.11011'in üstüne çıkmasıyla (Dügüum 2) finansal başarısızlık yüzdesinin \%17.6'ya düştüğü belirlenmiştir.

Cari Oran Düğüm 1'in, Düğüm 3 (öz sermaye karlılığı OK $\leq 0.11011$ ve cari oranı $\mathrm{CO} \leq 2.00486$ olan firmaların oluşturduğu alt grup) ve Düğüm 4 (öz sermaye karlılığ $\mathrm{OK} \leq 0.11011$ ve cari oranı $\mathrm{CO}>2.00486$ firmaların oluşturduğu alt grup) şeklinde iki alt gruba ayrılmasını sağlamıştır. Bu durum finansal sıkıntıdan kaçınmak isteyen dokuma, giyim eşyası ve deri sektörü firmalarının cari oranlarını 2.00486'nın üstünde tutmaları gerektiği şeklinde yorumlanabilir. Düğüm 3'te finansal başarısızlık oranı \%94.9 olarak belirlenirken, bu oran Dügüm 4 için \% 25 olarak hesaplanmıştır.

Finansal başarısızlık oranının \%17.6 olduğu Düğüm 2, duran varlıkların özsermayeye oranı faktörünün etkisiyle Düğüm 5 ( OK > 0.11011 ve DVOO $\leq$ 1.25782 olan firmaların oluşturduğu alt grup) ve Dügüm 6 ( $\mathrm{OK}>0.11011$ ve DVOO > 1.25782 olan firmaların oluşturduğu alt grup) şeklinde iki alt gruba ayrılmıştır. Düğüm 5 alt grubunda yer alan firmaların tümü finansal olarak başarılı şeklinde sınıflandırılmıştır. Özsermaye karlılığı 0.11011'in üstünde olması gerektiğine ve duran varlıkların belirli bir noktaya $(1,25782)$ kadar yabancı kaynakla finansmanına müsade eden bu durum sonucunda gruptaki tüm firmaların finansal olarak başarılı oldukları görülmüştür. Ancak duran varlıkların finansmanında daha fazla yabancı kaynak kullanılmasına işaret eden Dügüm 6 (OK > 0.11011 ve DVOO > 1.25782 olan firmaların oluşturduğu alt grup)'da finansal başarısızlık oranı artış göstermiş ve \%60'a yükselmiştir.

OK > 0.11011 ve DVOO > 1.25782 olan firmalarından oluşan alt grup (Düğüm 6), ticari alacakların aktiflere oranı bakımından Dügüm 7 (OK > 0.11011, DVOO $>1.25782$, TAAO $\leq 0.21431)$ ve Düğüm 8 ( OK >0.11011, DVOO > 1.25782, TAAO > 0.21431) olmak üzere iki alt gruba ayrılmıştır. Düğüm 7'de yani yukarıda sözü geçen ÖK ve DVÖO değerlerinin yanı sıra Ticari Alacakların Aktiflere Oranı 0.21431 'e eşit ve altında olduğu gruptaki firmaların tümüyle başarısız oldukları tespit edilmiştir. Diğer taraftan, ticari alacakların aktiflere oranının 0.21431 'in üstünde olması durumunda alt gruptaki tüm firmalar başarılı olarak sınıflandırılmıştır. Bu durum firmanın varlıklarının en az \%21'ini ticari alacakların oluşturmasının firmaların finansal başarıları üzerinde bir etkisi olduğunu ortaya koymaktadır. 


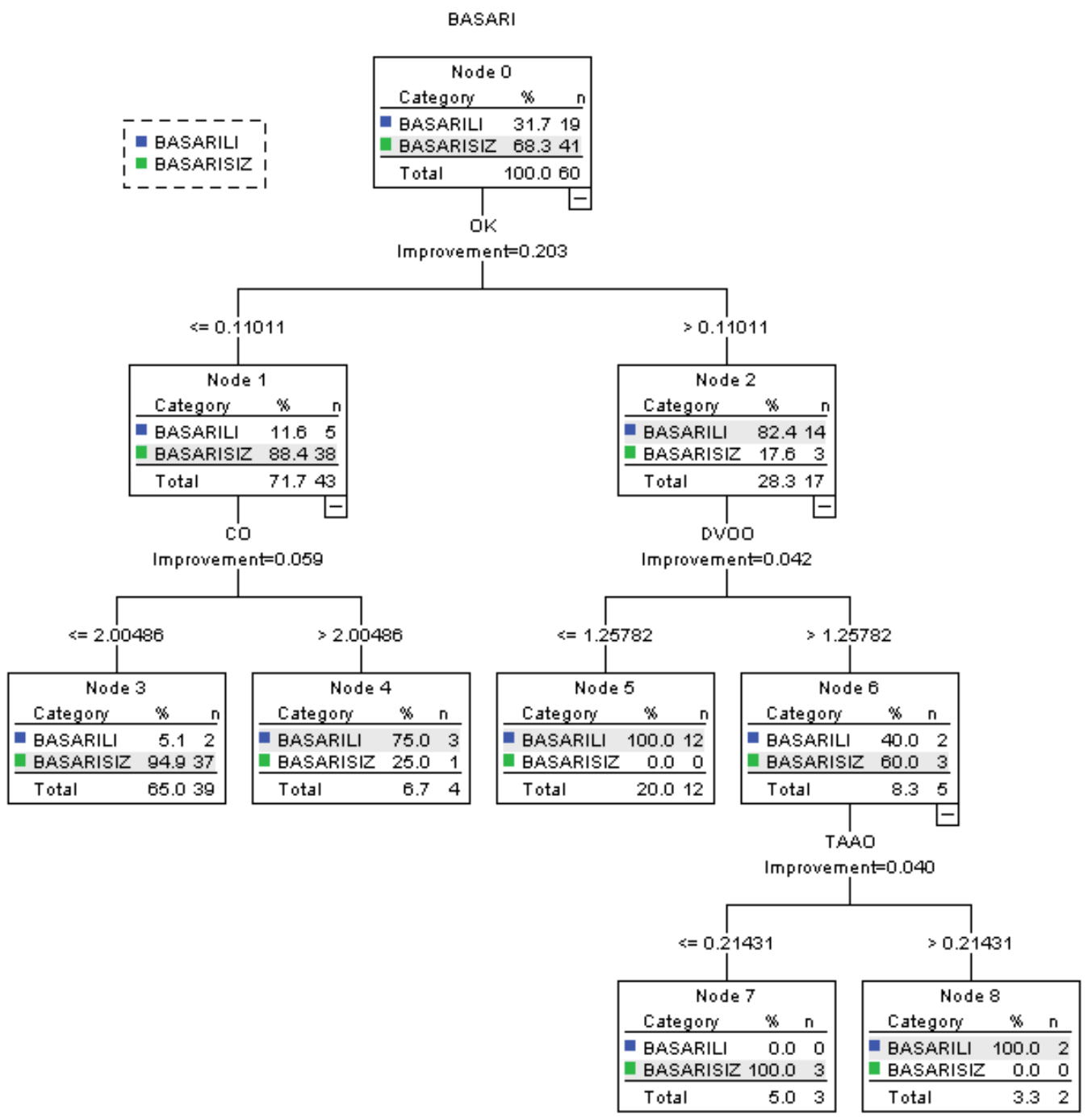

\subsection{QUEST Algoritmasına İlişkin Sonuçlar}

QUEST algoritmasına ilişkin sonuçlar incelendiğinde, birinci ağaç derinliğinde, Düğüm 0'da bulunan tüm firmalar, özsermaye karlılığı bakımından Düğüm 1 (özsermaye karlılı̆̆ $\mathrm{OK} \leq 0.0465$ olan firmalardan oluşan alt grup) ve Düğüm 2 (özsermaye karlılığı değeri $\mathrm{OK}>0.0465$ olan firmalardan oluşan alt grup) olmak üzere iki alt gruba ayrılmıştır. Aynı zamanda terminal düğüm noktalarını oluşturan Dügüm 1 ve Dügüm 2 değerlendirildiğinde finansal olarak başarılı ve başarısız firmaları sinıflandırmada en etkili olan faktörün özsermaye karlılığı olduğu tespit edilmiştir. İlk olarak Dügüm 1 değerlendirildiğinde, $\mathrm{OK} \leq 0.0465$ 
olan firmaların \% 89.2'sinin başarısız firmalardan oluştuğu görülmektedir. Diğer yandan özsermaye karlılığı değeri, OK > 0.0465 büyük olan firmaların ise \%34.8'lik kısmını başarısız firmalar oluşturmaktadır. Daha az ağaç derinliği sunan QUEST sonuçları, diğer algoritmalara nazaran doğru sınıflandırma konusunda daha düşük bir başarı elde etmiştir. Nitekim QUEST algoritması, başarısız firmaları \%80,5 ve başarıl1-başarısız firmaları ise \%80 oranında doğru sınıflandırmıştır.

Şekil 4. QUEST Sınıflandırma Ağacı

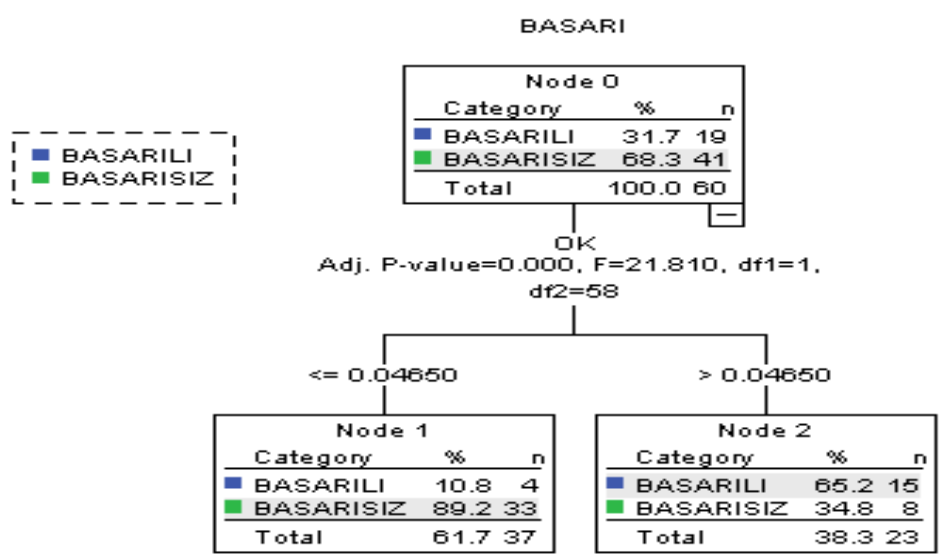

\section{Sonuç}

Tarihçesine bakıldığında pek çok ülkenin ekonomik kalkınmasında itici güç rolü üstlenen tekstil sektörü, etkinliğini günümüz dünyasında da sürdürmektedir. Sanayi konusundaki atılım ve girişimlerini ağırlıklı olarak tekstil sektörü sayesinde gerçekleştiren Türkiye için, en fazla dış ticaret fazlası veren sektörlerin başında yer alması ve istihdam yaratarak ekonomik kalkınmaya destek olması açısından söz konusu sektör daha ayrıcalıklı bir öneme sahiptir (UİB,2018:2-4). Tekstil sektörünün, finansal açıdan sağlıklı olması ve sürdürülebilirliğinin sağlanması ekonomik büyümeye katkısı açısından kilit öneme sahiptir. Bu kapsamda finansal başarısızlık durumlarının tahmin edilmesi ve bu durumu etkileyen faktörlerin tespit edilmesi, belirlenen risk unsurlarına karşı önlem alınmasında oldukça önemli bir rol oynamaktadır. Mevcut çalışmada Türkiye'deki dokuma, giyim eşyası ve deri sektörü firmalarının finansal başarısılıkları, oranlar yardımıyla tahmin edilmeye çalışılmış ve yöntem olarak CHAID, Exh-CHAID, CART ve QUEST algoritmaları kullanılarak en uygun tahminleme yönteminin belirlenmesi amaçlanmıştır.

Çalışmada ilk olarak uygulanan CHAID algoritması finansal başarısızlığ oranında doğru sınıflandırırken, genel olarak başarı-başarısızlık durumunu ise \%93.3 oranında doğru sınıflandırmıştır. Söz konusu algoritmaya ilişkin sonuçlar, finansal başarısızlıktan kaçınmak isteyen dokuma, giyim eşyası ve deri sektörü 
firmalarının özsermaye karlılı̆̆ı, cari oran, stok devir hızı ve faiz karşılama oranlarına özellikle önem göstermeleri gerektiğini ortaya koymuştur. Buna göre hissedarların yaptığı yatırımın karlılığının -0.02241 oranının altına düşmesi durumunda firmaların tamamiyle başarısız olacağı, ancak özsermaye karlılığının 0.09215'in üzerinde olması durumunda başarısızlığın \%22.2'ye düşeceği söylenebilmektedir. Ayrıca özsermaye karlılığına ek olarak stokların ne ölçüde etkin kullanıldığını gösteren stok devir hızının 2.52'nin üzerinde olması durumunda ise finansal başarısızlığın \%7.1'e düşeceği tespit edilmiştir. Son olarak hem özsermaye karlılı̆̆ hem de stok devir hızı için belirlenen oranları yakalayan ve üstüne, firmaların faiz ödemelerini karşılama kabiliyeti olarak açıklanan faiz karşılama oranı, 0.99022 değerinden büyük olan firmaların finansal başarısızlık oranlarının \%0 olduğu tespit edilmiştir.

Exh-CHAID algoritması ise firmaları sınıflandırmada, CHAID sonuçlarına kıyasla daha düşük bir performans göstermiş ve başarısız firmaları \%78 oranında doğru sinıflandırırken, genel sinıflandırmayı \%85 oranında doğru sınıflandırmıştır. Algoritma bulguları, finansal başarısızlığın önüne geçmede en çok dikkat edilmesi gereken faktörün özsermaye karlılığı olduğunu ortaya koymuş ve bu oranın CHAID sonuçlarıyla uyumlu olarak 0.09215 değerinden büyük olması gerektiğinin işaret etmiştir. Diğer taraftan cari oranın da finansal başarısızlığa göre yapılan sınıflandırma da önemli bir faktör olduğu tespit edilmiş ve bu oranın 1.5914 değerinin altında olmasının finansal başarısızlığı düşüreceğinin altı çizilmiştir. Son olarak nakit oranının da sınıflandırma için önemli bir faktör olduğu belirlenmiştir. Buna göre $\mathrm{OK} \leq 0,09215, \mathrm{CO} \leq 1.5914$ ve $\mathrm{NO} \leq 0.08778$ olan firmaların tamamiyle başarısız oldukları saptanmıştır. Ancak ilginç bir şekilde nakit oranının 0.020035 'ten büyük olması durumunda da firmaların tümüyle başarısız oldukları tespit edilmiştir. Örneklemin \%6,66 (4/60) dilimine denk gelen bu gözlemin, daha çok özsermaye karlılığındaki eksiklikten ve cari oran yetersizliğinden kaynaklandığı düşünülmektedir.

Çalışmada uygulanan bir diğer algoritma olan CART'nin, kullanılan karar ağacı algoritmaları arasında en doğru sınıflandırmayı yapan algoritmanın olduğu tespit edilmiştir. CART başarısız firmaları \%97.6 oranında doğru sınıflandırırken, genel sınıflandırmayı ise \%95 oranında bir doğruluk payı ile gerçekleştirmiştir. Algoritma bulguları genel hatlarıyla değerlendirildiğinde, finansal başarı ve başarısızlık ayrımında en önemli faktörün özsermaye karlılığı olduğu ve bu oranın 0.11'in üstünde bir değer almasının finansal başarı için önem arz ettiği tespit edilmiştir. CART algoritmasına ilişkin bir diğer önemli bulgu duran varlıkların özsermayeye oranının önemli bir faktör olduğu yönündedir. Buna göre duran varlıkların finansmanında yabancı kaynakların kullanım miktarı arttıkça, firmaların finansal olarak başarısızlaştıkları görülmektedir. Ayrıca aktifler içinde ticari alacakların payının artması finansal başarının yükseldiğini, azalması durumunda ise başarının düştüğünü ortaya koyan diğer bir bulgu olarak karşımıza çıkmaktadır. 
Son olarak çalışmada, QUEST algoritması uygulanmış ve söz konusu algoritma başarısız firmaları \%80,5 ve başarılı-başarısız firmaları ise $\% 80$ oranında doğru sınıflandırarak, diğer algoritmalara nazaran doğru sınıflandırma konusunda daha düşük bir başarı elde etmiştir. Ayrıca bulgular finansal olarak başarılı ve başarısız firmaları sınıflandırmada en etkili olan faktörün özsermaye karlılığı olduğunu ortaya koymuştur.

Çalışma sonuçları kullanılan CHAID, Exh-CHAID, CART ve QUEST algoritmaları arasında en doğru sınıflamayı yapan algoritmanın CART olduğunu ortaya koymuştur. Tahminleme yapmada QUEST ve Exh-CHAID algoritmalrının ise düşük bir performans gösterdiklerini söylemek mümkündür. Diğer taraftan mevcut çalışma sonucunda, dokuma, giyim eşyası ve deri sektörü firmalarının finansal başarı ve başarısızlık ayrımında en etkili faktörün özsermaye karlılığı olduğu tespit edilmiştir. Bu oranın 0.11 'in üstünde bir değer almasının finansal başarı için önem arz ettiği belirlenmiştir. Ayrıca cari oranın 2'nin altında olmasının ve duran varlık finansmanında kullanılan yabancı kaynak miktarının artmasının finansal başarısızlığı önemli oranda artırdığı bulgulanmıştır. Mevcut çalışmayı takiben farklı sektör ve algoritmalarla yeni çalışmalar yapılabileceği gibi, söz konusu çalışmanın finansal başarısızlıkta etkili olduğunu tespit ettiği oranlara ilişkin kritik değerlere ulaşmada nelere dikkat edilmesi gerektiği konusunda da çalışmalar yapılabilir.

\section{Kaynaklar}

Akkaya, G.C., Demireli, E. ve Yakut, Ü.H. (2009). İşletmelerde Finansal Başarısızlık Tahminlemesi: Yapay Sinir Ağları Modeli ile İMKB Üzerine Bir Uygulama. Eskişehir Osmangazi Üniversitesi Sosyal Bilimler Dergisi, 10(2), 187-216.

Alifiah, M.N. ve Tahir, M. S. (2018). Predicting Financial Distress Companies in the Manufacturing and Non-Manufacturing Sectors in Malaysia Using Macroeconomic Variables. Management Science Letters, 8 (2018), 593-604.

Altaş, D. ve Giray, S. (2005). Mali Başarısızlı̆̆ın Çok Değişkenli İstatistiksel Yöntemlerle Belirlenmesi: Tekstil Sektörü Örneği. Anadolu Üniversitesi Sosyal Bilimler Dergisi, 5(2), 13-28.

Altman, E.I. (1968). Financial Ratios, Discriminant Analysis and Prediction of Corporate Failure. Journal of Finance, 23(4), 589-609.

Altman, E.I, Marco, G. ve Varetto, F. (1994). Corporate Distress Diagnosis: Comparisons Using Linear Discriminant Analysis And Neural Networks (The Italian Experience). Journal of Banking and Finance, 18, 505-29.

Altman, E. I. (2000). Predicting Financial Distress Of Companies: Revisiting ZScore and ZETA Models. Stern School of Business, New York University.

Altman, E. I., Iwanicz-Drozdowska, M., Laitinen, E. K. ve Suvas, A. (2014). 
Distressed Firm and Bankruptcy Prediction in an International Context: A Review and Empirical Analysis of Altman's Z- Score Model. https://ssrn.com/abstract=2536340 (Erişim Tarihi, 18.09.2019).

Andreica, M. E. (2012). Early Warning Models of Financial Distress. Case Study of the Romanian Firms Listed on RASDAQ. Theoretical and Applied Economics, 20(5/582), 7-14.

Ashraf, S., Felix, E.G.S. ve Serrasqueiro, Z. (2019). Do Traditional Financial Distress Prediction Models Predict the Early Warning Signs of Financial Distress?. Journal of Risk and Financial Management, 12, 2-17.

Balcaen, S. ve Ooghe, H. (2004). 35 Years of Studies on Business Failure: An Overview of the Classical Statistical Methodologies And Their Related Problems. Working Paper, Ghent University, 248, 1-62. 2 s[E-P]

Beaver, W.H. (1966). Financial Ratios as Predictors of Failure. Empirical Research in Accounting: Selected Studie, Journal of Accounting Research, 5, 71-111.

Beaver, W. H., Correia, M. ve McNichols, M. (2011). Financial Statement Analysis and the Prediction of Financial Distress. Hannover, MA: Now Publishers.

Bellovary, J., Giacomino, D. ve Akers, M. (2007). A Review of Bankruptcy Prediction Studies: 1930-Present. Journal of Finance Education, 33, 1-42.

Blums, M. (2003). D-Score: Bankruptcy Prediction Model for Middle Market Public

Firms. http://www.minneapolisfed.org/mea/contest/2004papers/blums.pdf (Erişim Tarihi, 14.07.2019).

Boritz, J. ve Kennedy, D. (1995). Effectiveness of Neural Network Types For Prediction of Business Failure. Expert Systems with Applications, 9(4), 503512.

Bruwer, B.W.S. ve Hamman, W.D. (2006). Company failure in South Africa : Classification and Prediction by means of Recursive Partitioning. South African Journal of Business Management, 37(4), 7-18.

BSTB (2015).Türkiye Tekstil, Hazır Giyim, Deri Ürünleri Sektörleri, Strateji belgesi ve Eylem Planı, Bilim Sanayi, ve Teknoloji Bakanlığı, http://www.adaso.org.tr/WebDosyalar/Yayinlar/DisTicaretRaporlari/Türkiye\% 20Tekstil,\%20Hazırgiyim\%20ve\%20Deri\%20Ürünleri\%20Sektörleri\%20Strat eji\%20Belgesi\%20ve\%20Eylem\%20Planı\%202015-2018.pdf (Erişim Tarihi, 12.08.2019).

Chen, J., Marshall, B.R., Zhang, J. ve Ganesh, S. (2006). Financial Distress Prediction in China. Review of Pacific Basin Financial Markets and Policies, 9(2), 317-336. 
Delen, D., Kuzey, C. ve Uyar, A. (2012). Measuring Firm Performance Using Financial Ratios: A Decision Tree Approach. Expert Systems with Applications. 40 (10), 3970-3983.

Ertan, A. S. ve Ersan, Ö. (2018). Finansal Başarısızlığ 1 Belirleyen Etkenler: Türkiye İmalat Sektörü Örneği. Marmara Üniversitesi İktisadi ve İdari Bilimler Dergisi 40(2), 181-207.

Gör, Y. (2019). Finansal Başarısızlık Üzerine Bir Araştırma: BİST-100 Örneği. Uluslararası Yönetim ve Sosyal Araştırmalar Dergisi, 6(11):137-144.

Grzesiak, W. ve Zaborski, D. (2012). Examples of the Use of Data Mining Methods in Animal Breeding. In: A. Karahoca (Ed), Data mining applications in engineering and medicine, InTech.

Guan, Q. (1993). Development of Optimal Network Structures For BackPropagation Trained Neural Networks. Yayınlanmamış Doktora Tezi, University of Nebraska.

Gupta, V. (2017). Identifying Key Predictors of Default for Indian Companies using Cox Regression. International Journal of Engineering Technology Science and Research, 4(2), 97-111.

IBM Corp. Released (2015). IBM SPSS Statistics for Windows, Version 23.0. Armonk, NY: IBM Corp.

İçerli, M.ve Akkaya, G. (2006). Finansal Açıdan Başarılı Olan İşletmelerle Başarısız Olan İşletmeler Arasında Finansal Oranlar Yardımıyla Farklılıkların Tespiti. Atatürk Üniversitesi İktisadi Ve İdari Bilimler Dergisi. 20(1), 413421.

Kulalı, İ. (2016). Altman Z-Skor Modelinin BİST Şirketlerinin Finansal Başarısızlık Riskinin Tahmin Edilmesinde Uygulanması. Uluslararası Yönetim İktisat ve İsletme Dergisi. 12(27), 283-291.

Kumar, M.N. ve Rao, V.S.H. (2014) .A New Methodology for Estimating Internal Credit Risk and Bankruptcy Prediction under Basel II Regime. Computational Economics, 46(1):83-102.

Kurtaran Çelik, M. (2010). Bankaların Finansal Başarısızlıklarının Geleneksel Ve Yeni Yöntemlerle Öngörüsü. Yönetim Ve Ekonomi, 17(2),129-143.

Lee, K . C., Han, I. ve Kwon, Y.(1996). Hybrid Neural Network Models For Bankruptcy Predictions. Decision Support Systems. 18(1), 63-72.

Lee, T.S., Chiub. C., Chou, Y. ve Lud, C. (2006). Mining The Customer Credit Using Classification and Regression Tree and Multivariate Adaptive Regression Splines. Computational Statistics and Data Analysis, 50(4), 11131130. 
Mabe, Q. M. ve Lin, W. (2018). Determinants of Corporate Failure: The Case of the Johannesburg Stock Exchange. Working Book, https://mpra.ub.unimuenchen.de/88485/ (Erişim Tarihi, 21.09.2019).

Martin, A., Gayathri, V., Saranya, G., Gayathri, P. ve Venkatesan, P. (2011). A Hybrid Model For Bankruptcy Prediction Using Genetic Algorithm, Fuzzy CMeans And Mars. International Journal on Soft Computing, 2(1), 12-24.

Messier, Jr.,W. ve Hansen, J. (1988). Inducing Rules For Expert System Development: An Example Using Default And Bankruptcy Data. Management Science, 34(12), 1403-1415.

Nie, G., Wei, R., Lingling, Z., Yingjie, T. ve Yong, S. (2011). Expert Systems with Applications Credit Card Churn Forecasting by Logistic Regression and Decision Tree. Expert Systems With Applications, 38(12), 15273-15285.

Ohlson, J. A. (1980). Financial Ratios and the Probabilistic Prediction of Bankruptcy. Journal of Accounting Research, 18 (1), 109-131.

Pogue, M. (2008). Business Failure: Prediction and Prevention. Student Accountant, 40(6), 54-57.

Selimoğlu, S. ve Orhan, A. (2015). Finansal Başarısızlığın Oran Analizi ve Diskriminant Analizi Kullanılarak Ölçülmesi: BİST'de İşlem Gören Dokuma Giyim Eşyası ve Deri İşletmeleri Üzerine Bir Araştırma. Muhasebe ve Finansman Dergisi, 66, 21-86.

Shumway, T. (2001). Forecasting Bankruptcy More Accurately: A Simple Hazard Model. Journal of Business, 74, 101-124.

Sun, J.ve Li, H. (2008). Listed Companies' Financial Distress Prediction Based on Weighted Majority Voting Combination of Multiple Classifiers. Expert Systems with Applications, 35, 818-827.

Terzi, S. (2011). Finansal Rasyolar Yardımıyla Finansal Başarısızlık Tahmini: Gıda Sektöründe Ampirik Bir Araştırma. Çukurova Üniversitesi İ̈BF Dergisi, 15(1), 1-18.

Tsukuda, J. ve S. Baba. 1994. Predicting Japanese Corporate Bankruptcy in terms of Financial Date Using Neural Network. Computers and Industrial Engineering, 27, 445- 448.

UİB (2018). Türkiye Tekstil Sektörü ve Bursa. Uludağ İhracatçı Birlikleri AR-GE Şubesi Raporu. http://www.uib.org.tr/tr/kbfile/turkiye-tekstil-sektoru-ve-bursa (Erişim Tarihi, 14.02.2020)

Ural, K., Gürarda, Ş. ve Önemli, M.B. (2015). Lojistik Regresyon Modeli İle Finansal Başarısızlık Tahminlemesi: Borsa İstanbul'da Faaliyet Gösteren Gıda, İçki ve Tütün Şirketlerinde Uygulama. Muhasebe ve Finansman Dergisi, 67, 85-100. 
Vermeulen, E., Spronk J.ve van der Wijst, N. (1998). The Application of the Multi-factor in the Analysis of Corporate Failure, Zopounidis C. (Eds.) içinde Operational Tool in the management of Financial Risk. Springer, Boston, 5973.

Yerdelen Kaygın, C., Tazegül, A. ve Yazarkan H. (2016). İşletmelerin Finansal Başarılı ve Başarısız Olma Durumlarının Veri Madenciliği ve Lojistik Regresyon Analizi İle Tahmin Edilebilirliği. Ege Akademik Bakış, 16(1), 147159.

Y1lgör, A.G., Doğrul, Ü. ve Orekici, T.G. (2011). A New Approach to Predict Financial Failure: Classification and Regression Trees (CART). Journal of Modern Accounting and Auditing, 7(4), 329-339

Yılmaz, H. ve Yıldıran, M. (2015). Borsada İşlem Gören İşletmelerde Mali Başarısızlık Tahmini: Altman Modelinin BIST Uygulaması. Aksaray Üniversitesi İktisadi Ve İdari Bilimler Dergisi, 7(3), 43-49.

Zheng, Q. ve Yanhui, J. (2007). Financial Distress Prediction based on Decision Tree Models. In Service Operations and Logistics, and Informatics, 2007. SOLI 2007 (Augst). IEEE International Conference on (1-6). IEEE.

Zmijewski, M. E. (1984). Methodological issues Related to Estimation of Financial Distress Prediction Models. Journal of Accounting Research, 22, 5982. 